\title{
Hannah Arendt and the Boundaries of the Public Sphere
}

\author{
Alexey Salikov \\ $\mathrm{PhD}$, Leading Research Fellow, Centre for Fundamental Sociology, \\ National Research University Higher School of Economics \\ Address: Myasnitskaya str., 20, Moscow, Russian Federation 101000 \\ E-mail: dr.alexey.salikov@gmail.com \\ Greg Yudin \\ Senior Research Fellow, Laboratory for Studies in Economic Sociology, \\ National Research University Higher School of Economics \\ Professor of Political Philosophy, Moscow School of Social and Economic Sciences \\ Address: Myasnitskaya str., 20, Moscow, Russian Federation 101000 \\ E-mail: gregloko@yandex.ru
}

The world has changed markedly in the half a century since Hannah Arendt last inserted a blank piece of paper into her typewriter and typed the word "Judgment." Many new phenomena and changes have occurred on the political map, in the economy and technology, and in the minds of humans since that time. Some of these changes could be predicted long before their appearance, some of them emerged unexpectedly. We do not know how Arendt would react to the changes taking place in the contemporary world. However, we are confident that she would not have stayed aside silently. She was a passionate supporter of an active political life based on both, a pluralism of opinions and agonistic debates, on the one hand, and on "acting in concert," understanding and reconciliation between people, on the other. For Arendt only through the implementation of their essential plurality, can humans access and preserve their common world - which she understands as something "that is shared by many people, lies between them, separates and links them,

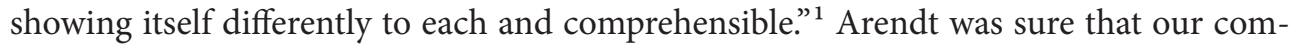
mon world can exist "only to the extent that many people can talk about it and exchange their opinions and perspectives with one another, over against one another. Only in the freedom of our speaking with one another does the world, as that about which we speak, emerge in its objectivity and visibility from all sides."

In the world of today, however, these fundamental elements of a healthy political life are threatened by significant transformations or even extinction. We can state with certainty that there is a crisis of politics in the modern world, resulting in the rise of the

\footnotetext{
(C) Alexey Salikov, 2018

(C) Greg Yudin, 2018

(C) Centre for Fundamental Sociology, 2018

1. Arendt H. (2005) The Promise of Politics (ed. J. Kohn), New York: Schocken Books, p. 128.

2. Ibid.: $128-129$.

DOI: $10.17323 / 1728-192 \mathrm{X}-2018-4-9-13$
} 
populist far-right movements, and accompanied by crises of truth, civility, and authenticity. These new political phenomena and changes would have challenged Arendt and would have made her reconsider the limits of political discussion. We can also assess with a confidence that the public sphere has changed dramatically since Arendt's lifetime and continues to undergo significant transformations, especially since emergence of the internet and social media.

Scholars use Arendt's concepts to develop various accounts of this new public sphere, yielding sometimes divergent conclusions.

Positive accounts usually emphasize that communication and presence in the public sphere becomes more accessible through the use of the internet and social media: modern technologies provide more opportunities for us to participate in political life, thereby erasing spatial and temporal boundaries. Yochai Benkler argues that this digital transformation of the public sphere "allows individuals to reorient themselves from passive readers and listeners to potential speakers and participants in a conversation." ${ }^{3}$ The internet and social media make it easier to access political life for non-professional political actors and for groups of the population that were often not represented in the public sphere in the past. Therefore, we can expect the formation of a more diverse and broader public sphere, compared to the one which existed in Arendt's lifetime.

However, the internet and social media have not fully justified the initially optimistic hopes of democratization and a revival of political life: in addition to the positive effect, new communication technologies have brought a number of negative points. Some features of social media communication contribute to the flourishing of harassment, mobbing and trolling, the spread of hate speech and the rejection of other opinions. At the moment, thanks to the internet and social media, people in one part of the public sphere unite and enrich our common world, in the other part they wage network wars with each other and do not want to hear the other points of view. As a result, many prefer to consort with members of communities based on similar views, consciously protecting themselves from interacting with people of other views. We notice not only the destruction of some boundaries by means of modern communicative technologies, but also the creation of new ones. These processes, taking place in the contemporary public sphere are also manifested in the increasing tendency to deny political opponents the opportunity to be adequately represented in the public space. Today, this model of political behavior is reproduced everywhere, regardless of political orientation and geographic location: in some cases, representatives of right-wing parties are marginalized and squeezed out of the public sphere, in other cases this happens to liberals or to supporters of left-wing views. As a result, the polarization and fragmentation of the public sphere, the formation of parallel communities with mutually exclusive views, are becoming ever clearer. The emergence of the internet and social media have not only increased transparency and political activism, but also made easier the manipulation and control of people, and this contributes to the blurring of the boundaries between the public and the private, between

3. Benkler Y. (2006) The Wealth of Networks: How Social Production Transforms Markets and Freedom, New Haven: Yale University Press, p. 213. 
lies and truth, between politics and economy. This blurring and disappearance of boundaries in some cases, and the formation of new ones in others, requires a rethinking of our understanding of the public sphere, and the new access to the changing human conditions. Arendt's theories can provide some promising perspectives for this. For Arendt was noted not only for her brilliant analysis of totalitarianism, her rigorous research of the human condition, and famous for noticing the intrinsic link between freedom and lying in politics, but also for her "endeavor to understand social and political processes of the present through the prism of some important changes of the past." ${ }^{3}$ However, how can all that help us to understand the political and social reality in the era of social media, "alternative facts," "fake news," "post-truths" and the dangerous self-isolation of people within their echo chambers? We do not know how Arendt would have answered this question, but we can try to analyze the political and social processes of the present from an Arendtian point of view, reconstructing it with the help of her published and unpublished writings, interviews and other material.

On the March 3oth-31st 2018, the 25th International Symposium "Paths of Russia" took place in Moscow. This anniversary conference featured the workshop "Hannah Arendt on the Limits of the Permissible: Public Sphere, Pluralism and Responsibility" as its central event. The workshop drew considerable attention from both academic scholars and the wider audience, and the Russian Sociological Review is proud to continue the discussion on the pages of our journal. In April 2018, we invited scholars in the fields of theoretical sociology, social philosophy, intellectual history and related disciplines in the social sciences and humanities to think on the problem of the boundaries of public sphere in connection with Arendt's ideas. In the call for papers we asked: "How can politics benefit from conflict and control it? Are there any positions and ideologies to be disqualified from public debate? In what ways are individuals responsible for upholding pluralism? How should the public sphere accommodate new types of political lies? How can Arendt's vision of the political be mobilized to answer the political challenges of the present day?"

The Special Arendt's Issue is a result of this "life of the mind." Roger Berkowitz analyzes the contemporary distaste for politics - Berkowitz refers to this phenomenon as "impossible politics" - from the point of Arendt's idea of reconciliation. This idea, according to Berkowitz, is especially important today, because reconciliation can lead to political solidarity, which the modern world stays in need for. Wolfgang Heuer discusses the question of the limits of lie and its prevention analyzing the use of such modern phenomena like "post-truth" and "fake news" produced by contemporary populist movements in order to undermine the credibility of politicians and mass media. The paper argues that Arendt's ideas of freedom of expression, of enlightened criticism, and Arendt's concept of a qualitative plurality are the foundations for the defense of truth and politics. Antonia Grunenberg rethinks Arendt's reflections on lying in the political realm in the context of modern digital era. The paper focuses on Arendt's explanation of the origins, the impact,

4. Salikov A., Zhavoronkov A. (2017) The Public Realm and Revolution: Hannah Arendt between Theory and Praxis. Estudos Ibero-Americanos, vol. 43, no 3, p. 522. 
and the ambivalence of lying in politics, and discusses the relevance of Arendt's thoughts for the understanding of the contemporary politics. John LeJeune argues that Arendt's theory provides the insight for the account of modern crises of truth, civility, and authenticity in the public sphere. The source of these crises author sees in the blurring of truth and opinion, in obscuring the public and the private in contemporary political discourse. Trevor Tchir discusses some ideas of Hannah Arendt's theory considering them as vital resources to meet the threats to pluralistic democratic action and to face the rise of populism and polarization in the media. As such a vital resource the paper recons Arendt's principle of resistance to totalitarianism and "responsibility for the world," the idea of the sensus communis, Arendt's imperative of factual truth-telling and her attention to the details of public. Alexey Salikov rethinks classical Habermasian approach to the phenomenon of public sphere from Arend's perspective focusing on its transformations since the emergence of social media. The paper examines the main actual changes taking place in the modern public sphere and concludes that the classical Habermasian concept of the public sphere requires a new approach. It is argued that some Arendt's ideas (self-organization through local communities, pluralism of opinions, competition in the public sphere) can be useful for elaboration of it. In his paper Anton Shablinskii conceptualizes the so-called mini-publics as the "oases of freedom" to demonstrate what type of political experience they can provide, and puts forward three conditions which are necessary for their functioning: self-selection of mini-publics, not requiring from minipublics to render strategic decisions, different attempts of the state to include such organizations in its sphere of influence must be monitored and suppressed. The paper argues that Arendt's vision of politics is necessary to answer the most topical questions of the mini-publics theory - on the essence of mini-publics, and how they can provide citizens with the political experience in the public deliberations. The paper of Iana Lepetiukhina is devoted to the emotions in political life, how Arendt's theory discovers the influence of emotions on the concepts of public space and plurality. The paper also examines the ideas of understanding of and reconciliation with the world demonstrating their significance in Arendt's theory as the essential prerequisites for existence of plurality and public space. The author argues that emotions eliminate both of them. Stefania Fantauzzi in her paper reflects on Arendt's ideas on civil disobedience. Setting out from the Arendtian concept of the law, bringing out its relational dimension and its ties to the consensus universalis it is argued that civil disobedience can be made consistent with the spirit of the law, brought up in Arendt's essay "Civil Disobedience." Alexey Zhavoronkov investigates the issue of applicability of Hannah Arendt's ideas of tradition, nihilism and crisis of thought to the analysis of contemporary radical conservatism. Grounded on the analysis of both Arendt's essays of the 1940s and 1950s, and the historical and modern forms of conservatism, the author explores the question why Arendt is important to the understanding of contemporary pseudo-conservatism, and explains why it is better to consider the crisis of judgement, tradition and dialogue in the public sphere in the broader Arendtian perspective. Artur Tretyak dedicates his reasoning to the Arendt's influence on Italian political philosopher Paolo Virno. The paper argues that Virno suggested revising and redefining 
the key concepts of Arendt's political philosophy in terms of Karl Marx's theory. The issue comes to its end with Anastasia Kalk's review on Richard J. Bernstein's book Why Read Hannah Arendt Now? (2018). Bernstein's book is a valuable and compact but comprehensive introduction to Arendt's political philosophy.

\title{
Ханна Арендт и границы публичной сферы
}

\author{
Алексей Саликов \\ Кандидат философских наук, ведущий научный сотрудник Центра фундаментальной социологии \\ Национального исследовательского университета «Высшая школа экономики» \\ Адрес: ул. Мясницкая, д. 20, г. Москва, Российская Федерация 101000 \\ E-mail:dr.alexey.salikov@gmail.com

\section{Григорий Юдин} \\ Кандидат философских наук, старший научный сотрудник лаборатории экономико-социологических \\ исследований Национального исследовательского университета «Высшая школы экономики» \\ Профессор политической философии Московской высшей школы социальных и экономических наук \\ Адрес: ул. Мясницкая, д. 20, г. Москва, Российская Федерация 101000 \\ E-mail: gregloko@yandex.ru
}

